\title{
THE TRACES OF THE LAST PLEISTOCENE GLACIAL MAXIMUM IN THE EASTERN KAMNIK-SAVINJA ALPS
}

\section{Borut Stojilković, M.A.}

Attemsov trg 8, SI-3342 Gornji Grad

e-mail: borut.stojilkovic@gmail.com

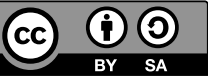

Original scientific article

COBISS 1.01

DOI: 10.4312/dela.47.1.127-141

\begin{abstract}
The area of the eastern Kamnik-Savinja Alps was glaciated in the time of the Last Pleistocene Glacial Maximum (LGM). The glacial landforms mentioned by the previous researchers and other landforms in the area were examined, gemorphologically mapped, morphographically and morphometrically analysed and a new map of the extent of the LGM was produced. The research revealed several glaciers in the area and that their sizes differed, primarily depending on the slope inclination direction.
\end{abstract}

Key words: Kamnik-Savinja Alps, the Last Glacial Maximum, Pleistocene glaciation, glacial geomorphology, geomorphology, Slovenia

\section{SLEDOVI ZADNJEGA VIŠKA PLEISTOCENSKE POLEDENITVE V VZHODNIH KAMNIŠKO-SAVINJSKIH ALPAH}

\section{Izvleček}

Območje vzhodnih Kamniško-Savinjskih Alp je bilo poledenelo v času zadnjega viška pleistocenske poledenitve. Preučili smo glacialne oblike, ki so jih omenjali prejšnji raziskovalci, ter preostale oblike na območju, jih geomorfološko kartirali ter morfografsko in morfometrično analizirali. S temi analizami smo določili meje viška zadnje poledenitve na tem območju. Raziskava je pokazala, da je bilo tu več ledenikov in da so se njihove velikosti razlikovale predvsem glede na smer naklona površja.

Ključne besede: Kamniško-Savinjske Alpe, zadnji višek poledenitve, pleistocenska poledenitev, glacialna geomorfologija, gemorfologija, Slovenija 


\section{INTRODUCTION}

The Kamnik-Savinja Alps are located in northern Slovenia and, together with the Julian Alps and Karavanks, compose Slovenian high mountain areas. The Kamnik-Savinja Alps range is aligned in E-W cardinal direction, its centre being the highest peaks. The highest mountains in the range are Grintovec (2558 m), Jezerska Kočna (2540), Skuta $(2532 \mathrm{~m})$, Kokrska Kočna $(2520 \mathrm{~m})$ and others. The study focuses on the eastern part of the mountain range, encompassing the major valleys of Matkov kot, Logar Valley, Robanov kot, Lučka Bela, Kamniška Bela and Kamniška Bistrica. The mountain range also includes the Dleskovec Plateau. The highest altitudes are up to $2558 \mathrm{~m}$ at its highest peak of the range (Grintovec), while other mountains' altitudes in the eastern part of the range vary from approximately $2000 \mathrm{~m}$ to $2394 \mathrm{~m}$ (Planjava).

Three main researchers studied the remains of the Last Pleistocene Glacial Maximum (LGM) in the area: Lucerna (1906), Šifrer (1961) and Meze (1966). Lucerna (1906) identified the majority of moraines and moraine ridges in the area. Śifrer (1961) reinterpreted Lucerna's findings in the area of the Kamniška Bistrica Valley and modified the map of the LGM's extent. Meze (1966) focused mainly on the area in the Upper Savinja Valley. His findings differ from Lucerna's (1906) significantly. According to

Figure 1: The Eastern Kamnik-Savinja Alps.

Slika 1: Vzhodne Kamniško-Savinjske Alpe.

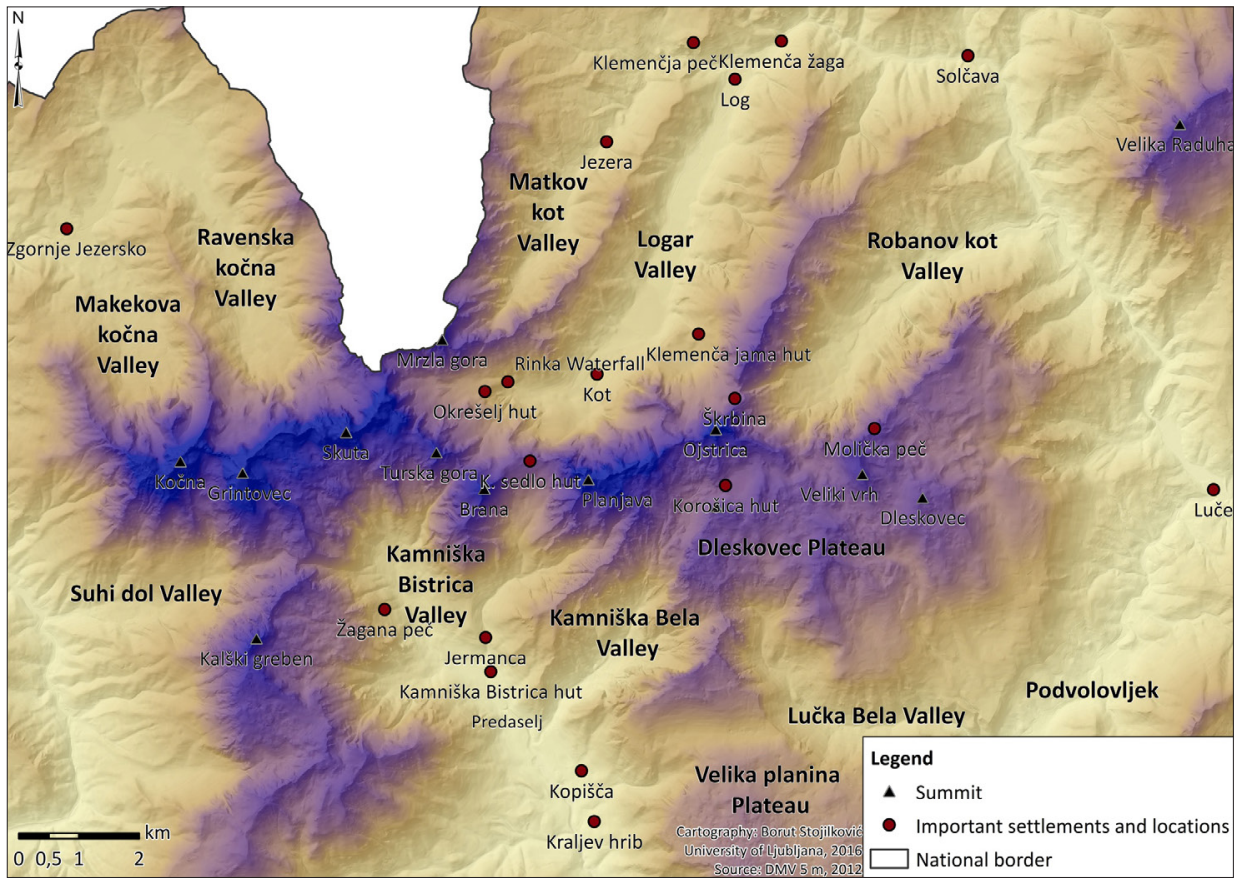


Meze (1966) the glaciers filled all the major valleys in his studied area (i.e. the Logar Valley, the Robanov kot Valley and the Matkov kot Valley). Fridl et al. (1995) collected all the previous literature and made a map of the LGM extent in the Kamnik-Savinja Alps. They concluded that the glaciers covered all the major valleys in the area and that the ice from the Dleskovec Plateau fed the glaciers in the neighbouring valleys, whereas the Kamniška Bistrica, the Logar and the Matkov kot valleys had their own cirque systems (Fridl et al., 1995).

The main purpose of the article is to provide an exact map of the geomorphological remains of the LGM in the eastern Kamnik-Savinja Alps and, secondly, to reinterpret the extent of the glaciation in the area. With this purpose we summarized the published literature, morphographically mapped the area, identified the glacial forms and morphometrically analysed them.

\section{METHODOLOGY}

The fieldwork encompassed re-checking glacial landforms identified by previous researchers (Lucerna, 1906; Kunaver, 1949; Meze, 1966; Fridl et al., 1995), examining LIDAR (2015) maps and determining possible glacial remains and mapping of all remaining moraine ridges, areas, covered with boulders, and cirques. These landforms were morphographically mapped onto 1:5,000 LIDAR topographic base maps. To distinguish glacial and fluvial sediments and to determine the ice-flow direction, different criteria were applied: clast shape and morphostratigraphy, where fluvial sediments have distinguishably more rounded shape, sedimentary-rock analysis for different rock types, proximity of gorges and brooks, where tendency for fluvial deposition was higher, and ice-flow direction on the bedrock.

The glacial landforms were morphographically and morphometrically analysed. Morphographic analysis encompassed examining the study area and identifying the glacial and other landforms relevant for the research (e.g. karstic landforms, fluvial and palaeo-fluvial sediments). For morphometric analysis of the landforms, a barometric GPS and altimeter were used directly in the field. Indirectly, LIDAR digital elevation models were used for further supporting and more detailed morphometric analysis. Hence, the following areas were examined: the Matkov kot Valley, the Logar Valley with Klemenča jama, the Robanov kot Valley and the surroundings (i.e. the Savinja River basin), the Dleskovec Plateau with its surroundings, parts of the Podvolovljek Valley bordering on the Dleskovec Plateau, the Lučka Bela Valley, the Kamniška Bela Valley and the Kamniška Bistrica Valley.

\section{FIELD EVIDENCE OFTHE PAST GLACIATIONS}

The erosional parts of the glaciers were morphographically analysed. No other glacial forms were found, other than the ones described by previous researchers (Lucerna, 1906; Kunaver, 1949; Šifrer, 1961; Meze, 1966). Those glacial forms are mainly snow kettles, which were formed with subglacial currents (Žebre, Stepišnik, 2014), and limestone pavements in the limestone areas, which have levelled topography (such as the Dleskovec 
Plateau) and had been previously identified (Meze, 1966). On steep slopes, the erosional glacial forms have already been eroded by fluvial processes or erased by weathering and in some instances even covered with screes or vegetation.

The field mapping and examination of glacier's accumulation forms was only partly possible. The most common glacial landforms found in the study area were moraines, moraine ridges and boulders. Those glacial landforms were located in parts of the studied valleys and on the Dleskovec Plateau. Moraines and other glacial traces were not found in the areas, where bedrock predominantly consists of dolomite, which weathers and fractures faster than limestone. The Kamnik-Savinja Alps have steep slopes, where moraines could not remain. They were eroded by water, which also formed several brooks on the slopes and alluvial fans. In the areas with impermeable rocks, the rivers accumulated fluvial and glacio-fluvial sediments, which could not always be distinguished from glacial deposits. In some cases the supposed glacial accumulations were covered with vegetation, rockfalls or Holocene sediments.

Due to these factors, the forms classified as sediments had to be clearly distinguishable by its form from fluvial deposits. Moraines had to be composed of at least three different rock types, which are found in the erosional part of the glacial area. Moreover, they had to fit the context of the glacial geomorphological surroundings.

Figure 2: Glacial geomorphological map.

Slika 2: Glacialni geomorfološki zemljevid.

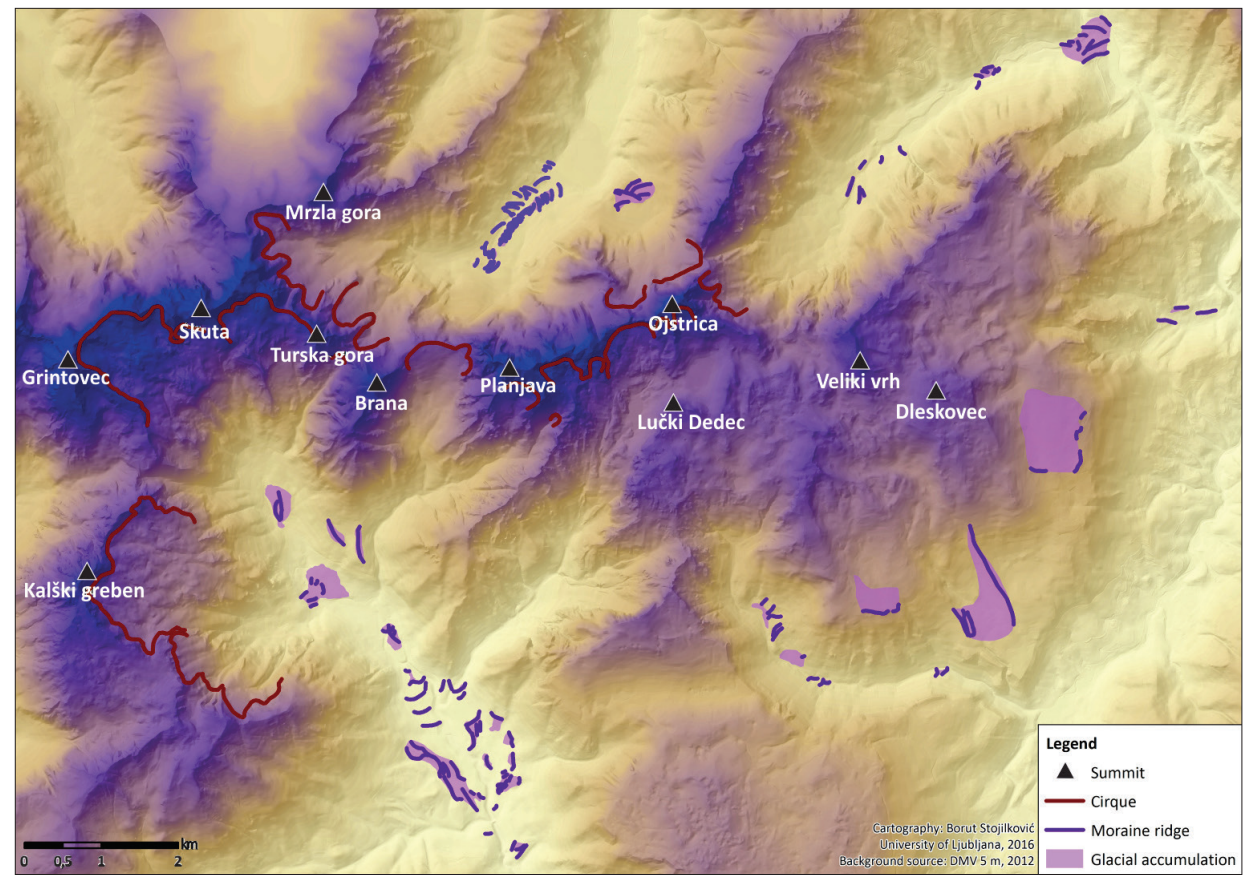




\section{I The Matkov kot Valley}

Lucerna's (1906) and Meze's (1966) findings on the length of the glacier in the Matkov kot Valley differ significantly. Lucerna (1906) estimated the terminal moraine altitude at approximately $900 \mathrm{~m}$ above the sea level, which is at the present spring of the brook Jezera, and its length $4.6 \mathrm{~km}$. Meze (1966) thought that this glacier was much longer - it did not fill only the Matkov kot Valley but it also flowed to the Logar Valley, where it joined the Logar glacier and stopped at the point where the Savinja River enters a narrow gorge. None of the glacial sediments in this valley, mentioned by previous researchers (Lucerna, 1906; Meze, 1966) were found during the fieldwork.

While examining the Matkov kot Valley, no glacial deposits were found. The valley is filled with extensive alluvial deposits. There are no permanent streams in the area, but the streams emerge when the snow melts and during the periods of higher precipitation. In both cases, waterfalls and some brooks are formed on the valley slopes. At the same time, the stream in the valley transports big amounts of material. There were no moraine sediments identified on the slopes. Because the cirque system did not provide as much ice, as other cirques in the neighbouring valleys did, the glacier's dimensions and its extractive power was not as big either. The moraines that were formed were considerably smaller

Figure 3: The Matkov kot Valley and its floor, filled with Holocene fluvial deposits (photo: B. Stojilković).

Slika 3: Matkov kot in njegovo dno, zapolnjeno s holocenskimi fluvialnimi sedimenti (foto: B. Stojilković).

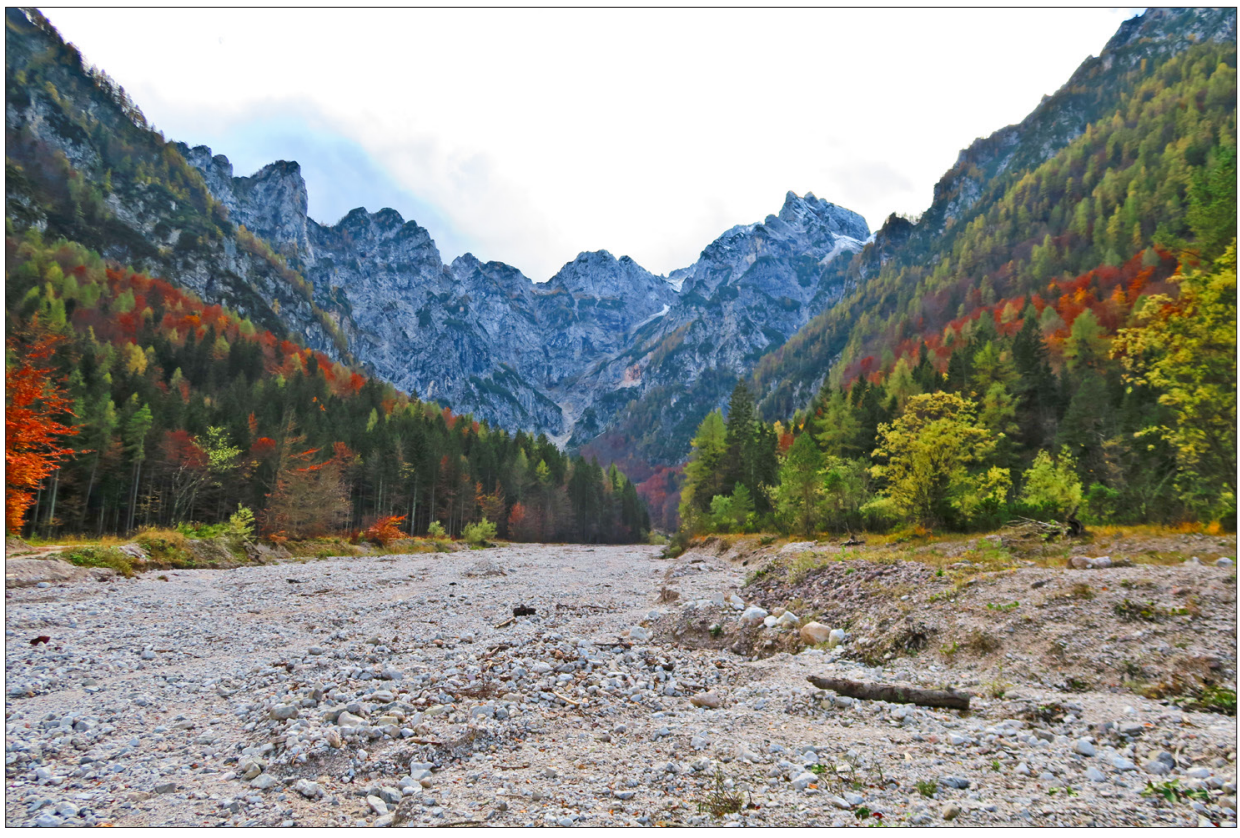


and situated lower on the mountain slopes. That is why it was even easier for water to erode them.

Even though no moraines were preserved to present day, the valley underwent glacial transformation and was partly glaciated. The valley has a relatively small cirque, where the ice was collected and then slid into the valley. Because there was no field evidence of past glaciations mapped and therefore no controlling heights obtained, the size of the glacier could not be calculated.

The glaciers of the Matkov kot Valley and the Logar Valley were not connected and they did not combine into a single flow as Meze (1966) claimed. Neither of the glaciers filled the entire valley floor with ice because the glacier's parts above the equilibrium line altitude were too small to produce the ice quantity that would fill the valleys. Meze (1966) explained that the hill at the end of the Logar Valley is a terminal moraine, which proves the existence of the glacier in whole of the valley. Our fieldwork revealed that the material, which builds the slope of this hill, is not composed of glacial sediments, but of fluvial ones. The rocks are fluvially transformed and stratified. They were deposited by the brook flowing from the Matkov kot Valley. There are several larger blocks at the end of the Logar Valley, which Meze (1966) attributed to the Matkov kot glacier. The stones are of the same structure as surrounding slope on the eastern side of the valley, which makes them dropstones, rather than glacial boulders (Stojilković, Stepišnik, Žebre, 2013).

\subsection{The Logar Valley}

Lucerna (1906) and Meze (1966) mapped the extent of the glacier in the Logar Valley similarly. They both thought that the glacier filled the entire valley floor and stretched from the cirque of Okrešelj to the very end of the valley. The difference between the two studies is that Meze (1966) thought that the glacier was slightly bigger (Lucerna, 1906; Meze, 1966).

All the geomorphological evidence in the Logar Valley, presented in the previous literature, was re-checked by Stojilković, Stepišnik and Žebre (2013), who concluded that there were two glaciers in the area: the smaller one in the Klemenča jama Valley and the main glacier in the Logar Valley itself. The latter stretched from $1945 \mathrm{~m}$ to $860 \mathrm{~m}$ above the sea level, which is considerably less than it had been estimated before. The Logar Valley glacier ended at the terminal moraine on the elevation of $860 \mathrm{~m}$ above the sea level. The glacier in the Klemenča jama Valley stretched between the altitudes of 1880 and $1135 \mathrm{~m}$ (Stojilković, Stepišnik, Žebre, 2013). The glacial remains in the study made by Stojilković, Stepišnik and Žebre (2013) were re-examined once again, but no further changes were made to the glacial-geomorphological map of the area. 
Figure 4: The cirque Okrešelj above the Logar Valley (photo: B. Stojilković). Slika 4: Krnica Okrě̌elj nad Logarsko dolino (foto: B. Stojilković).

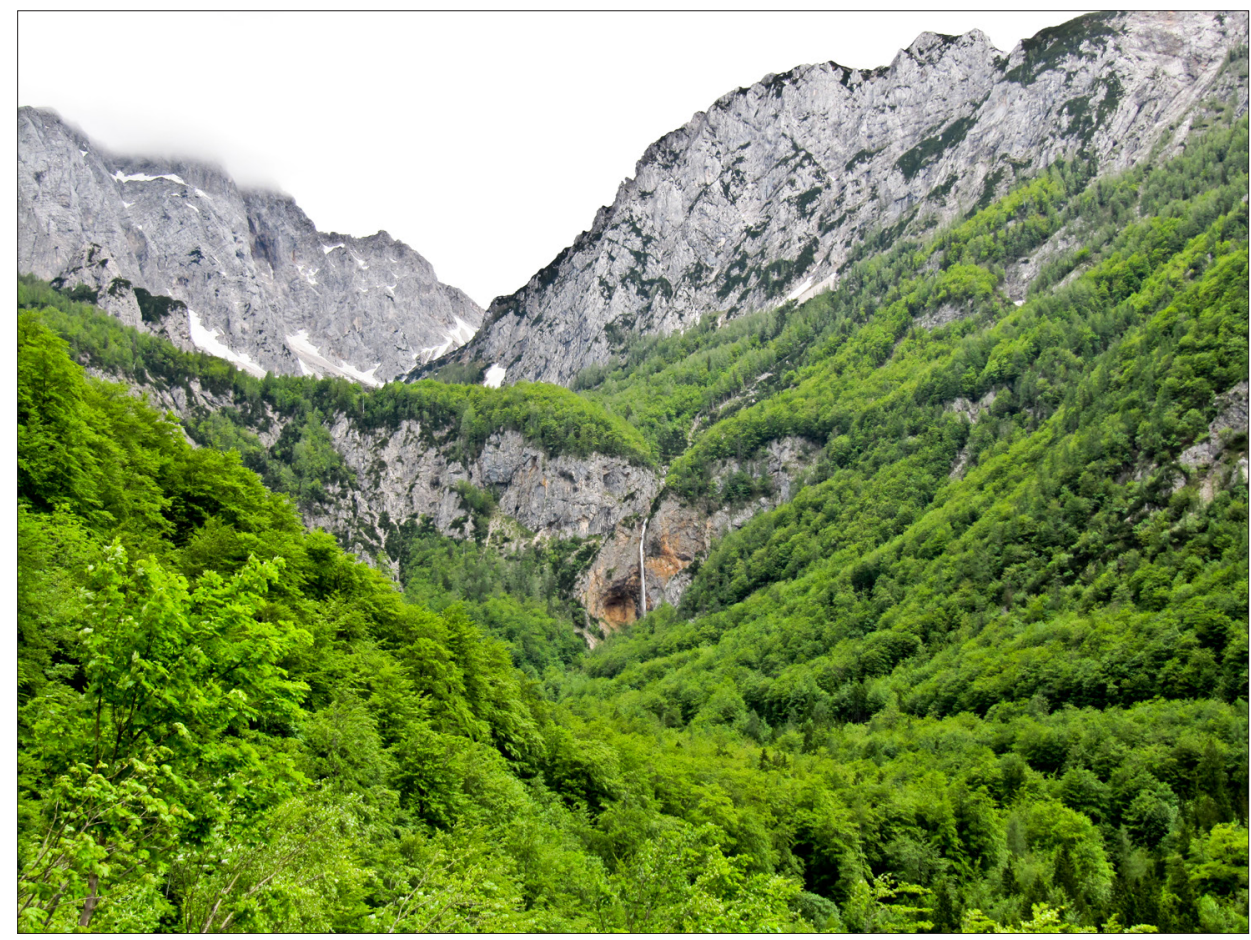

\subsection{The Robanov kot Valley}

The ice from the Dleskovec Plateau was partly sliding into the Robanov kot Valley and feeding the glacier there. The main source of the ice was not from the cirques as in the Logar Valley or the Matkov kot Valley, but the ice from the karst plateau.

The erosional part of the Robanov kot glacier ended at the altitude of $915 \mathrm{~m}$, where the first moraines were located during the fieldwork. The moraines in the valley are well preserved and frequent on both slopes of the valley, however, not preserved at the same altitudes on both slopes. The moraines in the valley floor were fluvially eroded in Holocene by the Bela Stream that flows during the snow-melt period through the entire valley and all year long in the lower part of the valley, where the waters from other brooks join. The brooks on both slopes eroded the moraines of the retreating glacier or covered the moraine material with the debris that today forms alluvial fans. There are four bigger alluvial fans on northern slope of the valley and three on the southern one.

The first terminal moraine complexes that were deposited by the retreating glacier are at the altitude of 915-790 $\mathrm{m}$ and are situated near the Robanova planina mountain hut. Chronologically connected to these moraines are lateral moraines on the southern slope 
of the valley, which rise from the left bank of the Bela Stream up to the elevation of approximately $900 \mathrm{~m}$. The same moraine ridges were identified by Lucerna (1906), who dated them to Bühl stadium, and Meze (1966). Higher up the valley, the moraines are not preserved. They are most likely to be covered with rock avalanches from the neighbouring mountains (i.e. Krofička, Škrbina, Ojstrica, Molička peč and others) or with alluvial deposits of the Bela Stream. The moraines in the Robanov kot Valley are at similar altitudes as the moraines in the Logar Valley, where they are at approximately $1004 \mathrm{~m}$ (Stojilković, Stepišnik, Žebre, 2013). This indicates that the glaciers shared similar ELA characteristic and that the palaeo-microclimatic conditions affected the two glaciers in the same way.

Another patch of moraine material was found on the left bank of the Bela Stream to the west of Lukežev graben Brook. In this area, two moraine ridges with typical profiles showing the moraine structure were found. They are up to the elevation of $830 \mathrm{~m}$.

The presence of alluvial fans confirms the absence of moraines between the areas of the Lukežev graben Brook and the Knežak Brook. The third set of moraine ridges is to the west of Knežak Brook. The lithological structure of the moraines proves that the ridges were accumulated by the glacier and that they are not made of rockfall or fluvial accumulations. The clast supported lateral moraines succeed each other on the

Figure 5: Moraine material on the southeastern slope of the Robanov kot Valley (photo: B. Stojilković).

Slika 5: Morenski material na jugovzhodnem pobočju Robanovega kota (foto: B. Stojilković).

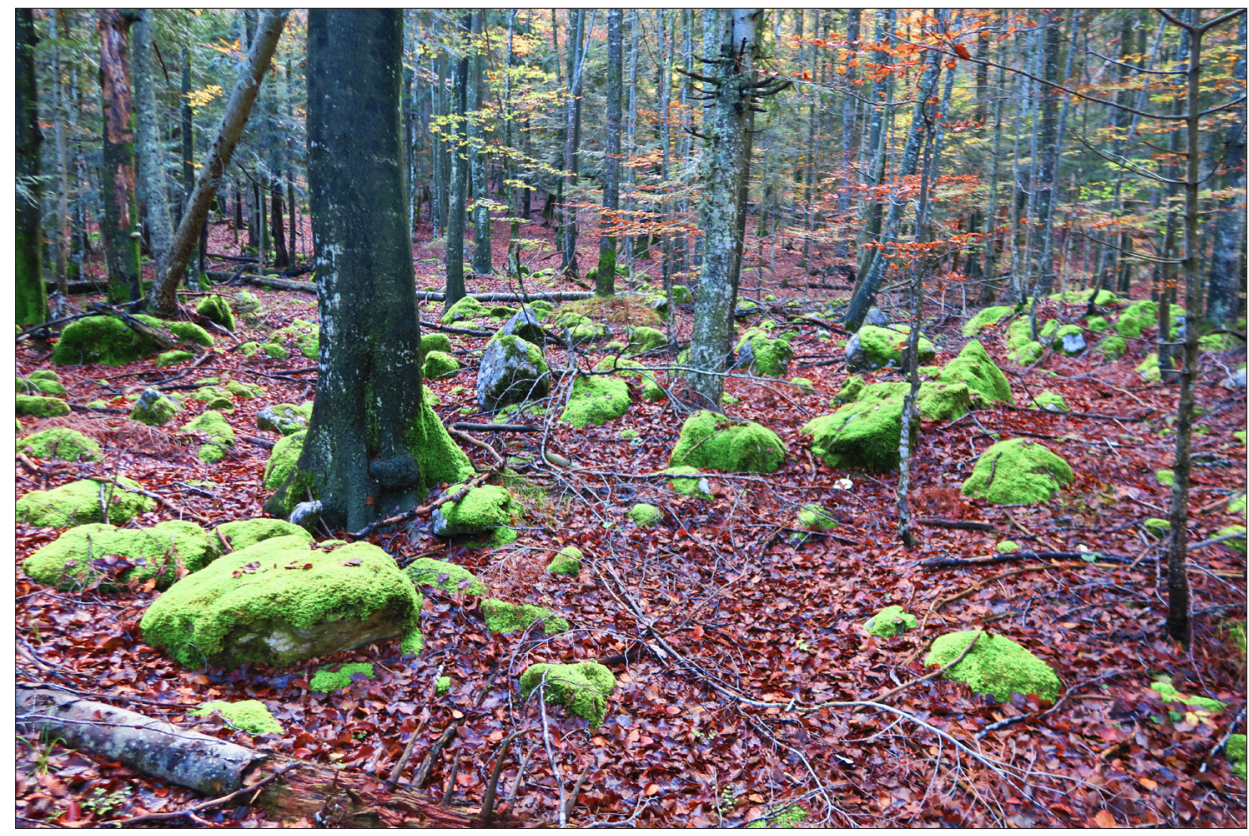


southern bank of the Bela Stream and have their moraine correspondents on the northern bank. The last moraine ridge before the terminal moraine complex lies to the south of the Roban farmstead and is just below the altitude of $700 \mathrm{~m}$. There are no moraines preserved on the northern slope of the valley in this area due to the dolomitic lithological structure.

The lateral-terminal complex commences at the altitude of approximately 750 metres with a lateral moraine on the southern slope of the valley. There are several moraine ridges preserved in the area and today, a farm is situated just above them. There are three ridges building the lateral moraine and they are linked to the terminal moraine ridge on the left (western) bank of the Savinja River. The Robanov kot glacier did not flow down the Savinja River Valley, but it ended when it entered the valley. Lucerna (1906) and Meze (1966) did not find any glacial deposits of the Roban glacier downstream.

The Roban glacier ended at the well-preserved terminal moraine, which lies on the other bank of the Savinja River than the valley itself. The particles in the moraine range from boulders that have a diameter of several metres to silt particles. They are mainly limestones or dolomites. Granulation analysis of the moraine material indicated that the biggest part of the fractions vary from $8 \mathrm{~mm}$ to $5 \mathrm{~cm}$ (Meze, 1966). Similar to what was discovered in this research, Meze (1966) morphometrically analysed it as $300 \mathrm{~m}$ high. The glacier flowed to the end of the valley, over the area of the present Savinja River riverbed. It ended at the slope of the Raduha Mountain.

\subsection{The area between the valleys of the Robanov kot and the Lučka Bela}

Previous researches (e.g. Meze, 1966; Fridl et al., 1995) mapped some other moraine and cirque remains in the close vicinity of the Roban glacier, just before the Savinja River enters the gorge of Igla. The cirques are on the elevation of $1000 \mathrm{~m}$ and the glacier was supposed to reach the Savinja River at $750 \mathrm{~m}$ above the sea level (Meze, 1966; Fridl et al., 1995). The supposed moraine material was re-examined and it was classified as alluvial material, deposited by the brooks flowing down the Dleskovec Plateau in the northeast direction. The material in the accumulation is of the same lithological structure, fluvially transformed and partly stratified. The rocks in the Savinja riverbed, which are mainly light-grey limestones, are up to several meters in diameter and were brought by rockfalls from either the Raduha Mountain in the northeast or from the Veža Mountain (the Dleskovec Plateau) in the southwest.

Previous literature (Lucerna, 1906; Meze, 1966; Fridl et al., 1995) suggests that a glacier flowed from the Dleskovec Plateau in the direction of the village Luče. The glacier had its cirques to the north of the peak Smrekovec $(1613 \mathrm{~m})$ and next to the peak of Ojstri vrh (1359 m) (Meze, 1966), it was four km long and ended at approximately $700 \mathrm{~m}$ above the sea level (Lucerna, 1906). Lucerna (1906) named it 'Dol Glacier'. Meze (1966) supposed that the cirques had a pre-glacial form of karst depressions. When the glacier reached Ojstri vrh, it diverged into two parts (Meze, 1966). Lucerna (1906) thought that the two parts of the glacier did not merge, but Meze (1966) thought differently. 
Figure 6: The two valleys of the glacier that was directed towards the Luče village (photo: B. Stojilković).

Slika 6: Obe dolini ledenika, ki je tekel proti vasi Luče (foto: B. Stojilković).

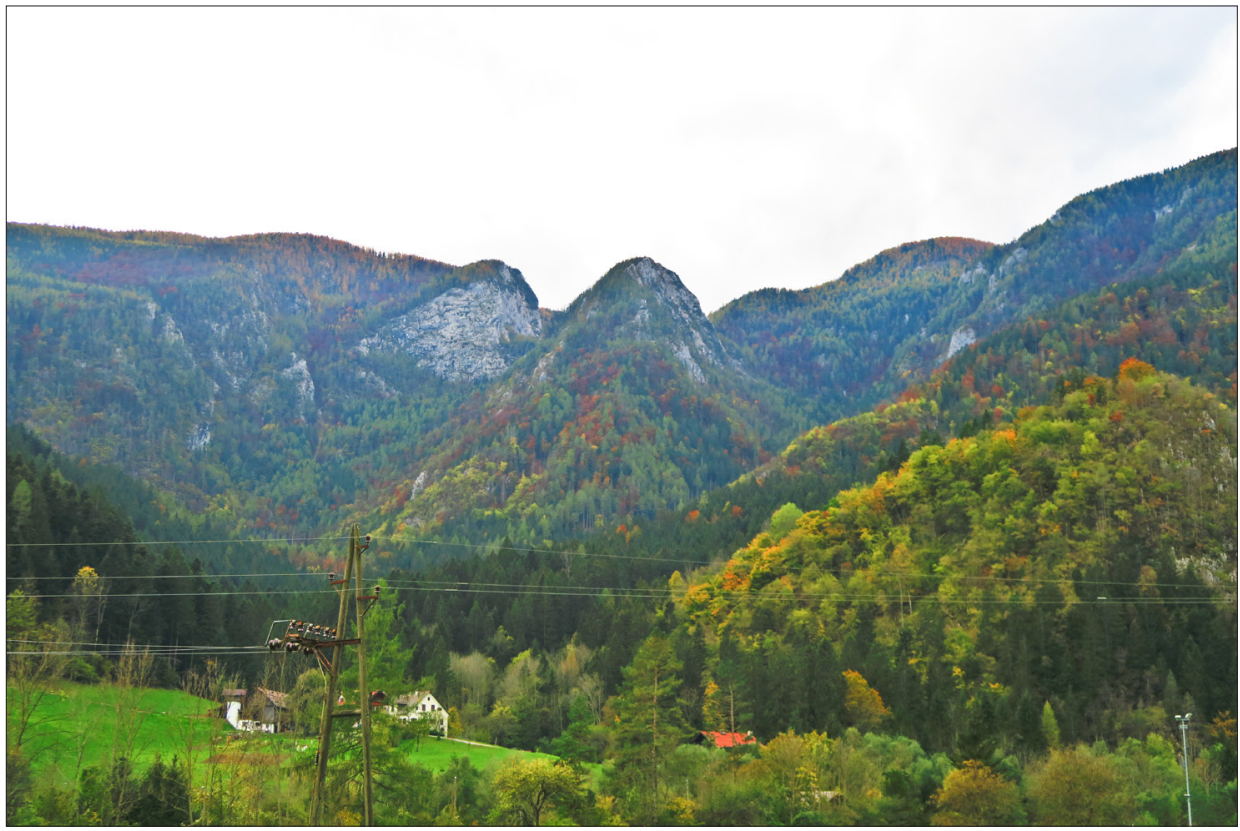

Because of the close proximity of the Savinja River, which could erode glacial accumulations, both banks of the river were examined. There were no traces of glacial accumulation found on the left bank of the river. This means that the glacier did not dam the Savinja River, but it stopped at a higher altitude of the plateau's slope, where lateral moraine ridges were located. It cannot be clearly located where the glacier terminated because of strong denudation and erosion on steep slopes what was also claimed by Meze (1966). Any traces of moraine material were not found on the slopes of the southern part of the valleys because they could also be covered with rockfalls that cover significant part of the area. Some moraine areas are also covered with screes, so the analyses of the moraine ridges in that area were limited only to the moraines on the surface.

\subsection{The Dleskovec Plateau}

Lucerna's (1906) and Meze's (1966) research results for the Dleskovec Plateau do not differ significantly. Several moraine ridges and other moraine material were found on the plateau, and two glaciers were identified there: 'Ravno polje' glacier in the southwestern part and 'Planinšek' glacier in the southeastern part of the plateau (Lucerna, 1906; Meze, 1966; Fridl et al., 1995). According to Lucerna (1906), the two glaciers accumulated large quantities of moraine material in the terminal and lateral moraines. The western glacier 
Figure 7: Moraine material on the Dleskovec Plateau near Podvežak (photo: B. Stojilković). Slika 7: Morenski material na Dleskovški planoti na planini Podvežak (foto: B. Stojilković).

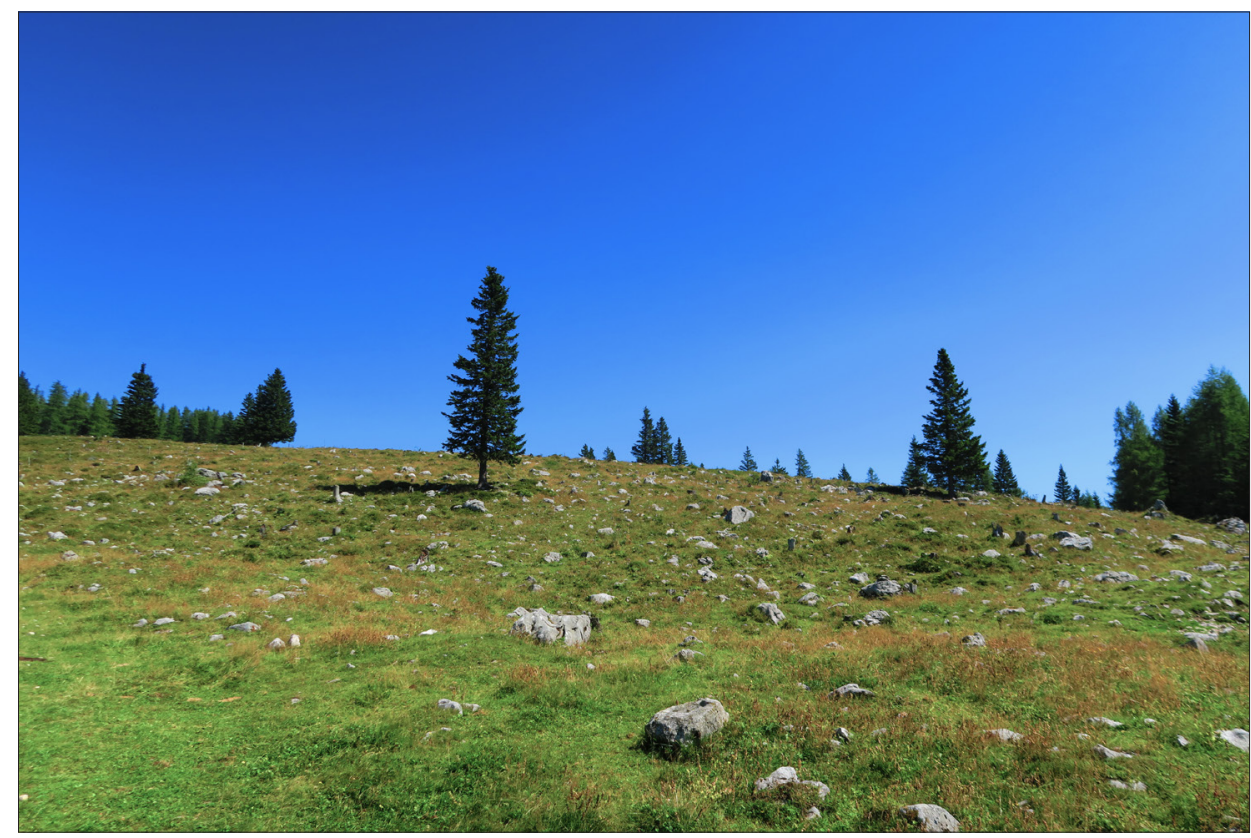

measured $2.07 \mathrm{~km}$ in length and did not flow below $1440 \mathrm{~m}$ above the sea level, whereas the eastern glacier on the plateau was $4.2 \mathrm{~km}$ long and flowed down to the altitude of 1000 m (Lucerna, 1906).

Lucerna (1906) thought that the eastern glacier and the glacier in the Lučka Bela Valley did not merge. We came to the same results in this research: the absence of moraine material in the vicinity of the edge of the plateau proves that the eastern glacier did not reach the plateau edge. There are several moraine ridges on the plateau that clearly show the direction of the glacier's flow. Both ice-masses on the plateau flowed in the southern direction towards the Podvolovljek Valley, but they stopped before reaching the escarpment. The moraines are mainly preserved on limestone surface, whereas there are no glacial traces on dolomite bedrock. However, the continuity of the preserved moraines shows the limits of the glacier. The areas on the outskirts of the plateau were not glacially transformed. In those areas many sinkholes can be found in permeable bedrock.

There were some speculations that parts of the ice flowed from the Dleskovec Plateau towards the Lučnica River, but never reached it (Meze, 1966). Lucerna (1906) mapped a Riss moraine even further down - on the eastern bank of the Lučnica River. Our research revealed that the ice did not flow over the edge of the plateau on the southeast over Planina Ravne to Podvolovljek. On the escarpment between Podvolovljek and Planina Ravne 
(far eastern part of the plateau), no glacial sediments were found. They could not have been fluvially eroded because no larger stream runs across the area. The glacier's limits were at the lateral moraine on the plateau itself.

\subsection{The Lučka Bela Valley}

The second valley that was fed by the ice from the Dleskovec Plateau is the Lučka Bela Valley. Previous literature (Lucerna, 1906; Meze, 1966; Fridl et al., 1995) mentions the moraine material in the valley. Lucerna (1906) dated it to Bühl stadium. The glacier in the valley was $6.25 \mathrm{~km}$ long, and it reached the altitude of $700 \mathrm{~m}$ (Lucerna, 1906).

The moraines and moraine material are only partly preserved in the valley. The majority of the moraine material was eroded by the Lučka Bela River. The valley is relatively narrow and the relief energy big. Hence, the water energy is big as well. Therefore, there are no traces that would inevitably prove the existence of a glacier. However, there is some glacially-deposited material remaining: the first is in the upper part of the valley where there are traces of the ice flowing from the Dleskovec Plateau. The traces are preserved in the forms of lateral and ground moraines. There are only smaller moraine ridges in the central part of the valley. There is some moraine material remaining just before the valley narrows even more, i.e. where the river leaves the glacial part of the valley and enters the canyon. That is also the furthest part where the Lučka Bela glacier came. There is a ridge with cemented material on the southern side of the riverbank at the lower end of the valley, but it could not be possible to connect it to Last Pleistocene Glacial Maximum.

\subsection{The Kamniška Bela Valley and the Kamniška Bistrica Valley}

There were two glaciers flowing from different directions and then merging together in the Kamniška Bistrica Valley. The first one was in the Kamniška Bela Valley and was fed by the ice from the Dleskovec Plateau. The second one was in the Kamniška Bistrica Valley and it started in the group of cirques right below the central part of the KamnikSavinja Alps. The two glaciers joined and together formed a lateral-terminal moraine complex just after Kraljev hrib.

Lucerna (1906) named both glaciers collectively 'Feistritz' glacier. It was $8.05 \mathrm{~km}$ long, its terminus was at the elevation of $500 \mathrm{~m}$, and its surface was 2458 ha (Lucerna, 1906). Lucerna (1906) identified another glacier right under the Kamniško sedlo Pass and Planjava, and named it 'Freithof' glacier. The glacier ended at approximately $880 \mathrm{~m}$ above the sea level and was $2.75 \mathrm{~km}$ long; the area between the two glaciers was filled with gravel (Lucerna, 1906). Systematic research of the valley revealed that the glaciers mentioned by Lucerna (1906) were not separate ones, but formed a single ice mass.

The Kamniška Bistrica glacier had three main cirques. The western one was under Kalški greben, the central one was under the mountains of Grintovec, Skuta and Brana, and the eastern between the Brana Mountain, the Kamniško sedlo Pass and the Planjava Mountain. The traces of both glacial parts are preserved in lateral moraines surrounding 
Jermanca. The ridges are clearly visible and distinguishable. The eastern part flowed into the valley of the Sedelšček Brook, whereas the western one into the Krvavec Brook. The western part accumulated a moraine northwest from the mountain hut in the Kamniška Bistrica Valley. Where the mountain hut stands today, the two parts merged into a single Kamniška Bistrica Glacier. The glacial traces (i.e. the moraine material) are partly covered from there onwards with Holocene alluvial accumulations.

Glacial deposits were found at the approximate altitude of 580 metres and continued in a lateral-terminal moraine ridge complex to its end south of Kraljev hrib, where last moraine ridges were located. The moraine material was partly eroded by the Kamniška Bistrica River or covered with alluvial accumulations of brooks flowing from both slopes of the valley and form alluvial fans. In some cases, the moraine ridges could not be identified with certainty because of the high relief energy of the surrounding slopes. Therefore, only clearly distinguishable moraines were taken into consideration. This moraine complex was deposited by both glaciers: the one from the Kamniška Bistrica Valley and from the Kamniška Bela Valley. The two glaciers merged to the south of Predaselj at the elevation of approximately $570 \mathrm{~m}$, where the confluence of the rivers from both valleys today is. At Predaselj, the retreating glacier of Kamniška Bistrica was supposed to come to a standstill (Šifrer, 1961).

Šifrer (1961) claimed that the glacier at its largest extent stretched right to the part where the Kamniška Bistrica Valley narrows. In this research, glacial deposits were found in the same area. Lucerna (1906), however, thought that the glacier stretched only to Kopišča.

Šifrer (1961) thought that there were two stages in the glaciation in the Kamniška Bistrica Valley because the moraine at Kraljev hrib is covered with partly cemented breccia and because of the moraine lying 40-50 m at Črni hrib, which both according to the author underwent periglacial transformation. However, this research considered only the moraines belonging to the Last Pleistocene Glacial Maximum. Šifrer (1961) supported his argument with the absence of cemented moraines upstream in the valley, where only non-cemented moraines were found.

The glacier in the Kamniška Bistrica Valley was most likely smaller according to its size than the glacier in the Kamniška Bela Valley. Hence, the glacier in Kamniška Bela Valley deepened the valley to a greater extent than the glacier in the Kamniška Bistrica Valley. After both glaciers retreated, the Kamniška Bistrica started to level the surface. Before the confluence with the Bela River, which flows down the Kamniška Bela Valley, the Kamniška Bistrica eroded the bedrock and created a gorge. The process began after the Pleistocene glaciers retreated and the Kamniška Bistrica River started to vertically carve the rocks. The reason for this is high gradient, which causes quick vertical erosion.

\section{CONCLUSION}

The research on the LGM was made in the area of the eastern Kamnik-Savinja Alps, where geomorphological mapping of the glacial landforms took place. The fieldwork encompassed re-examining the glacial traces mentioned in the so-far literature (Lucerna, 
1906; Kunaver, 1949; Šifrer, 1961; Meze, 1966; Fridl et al., 1995) in combination with all other glacial and fluvio-glacial landforms.

The geomorphological research encompassed the eastern part of the Kamnik-Savinja Alps: the Matkov kot Valley, the Logar Valley, the Robanov kot Valley, the Dleskovec Plateau and all its slopes, the Lučka Bela Valley, the Kamniška Bela Valley and the Kamniška Bistrica Valley. Among these are also the areas that the previous researchers mention as being affected by the LGM. The extent of LGM in the area was $40.9 \mathrm{~km}^{2}$, which excludes the Matkov kot glacier, where no moraine material has been preserved, and hence, a reconstruction could not be made.

The research revealed that the glaciers in the area did not cover such a big surface as claimed by the previous researchers (Lucerna, 1906; Kunaver, 1949; Šifrer, 1961; Meze, 1966; Fridl et al., 1995). The glaciers from the Matkov kot Valley and the Logar Valley did not merge at the ends of both valleys, but were significantly shorter. The ice from the Dleskovec Plateau flowed into Robanov kot only in smaller part, eastern from the Ojstrica Mountain. The glaciers on the slopes in the area between the Robanov kot Valley and the Lučka Bela Valley had different sizes than it was previously thought. And lastly, the cirque systems of the glaciers in the Kamniška Bistrica Valley, the Logar Valley and the Matkov kot Valley separated them.

The research on glacial remains from the time of the LGM provides a basis for further geomorphological work: on the basis of the sizes of cirques, moraines and moraine ridges it is possible to reconstruct the topography of the glaciers in the area, to determine its palaeo-equilibrium line and to reconstruct the palaeo-climatic conditions that took place in that period of Pleistocene.

\section{References}

DMV 5 m - Digitalni model višin. 2012. Ljubljana, Geodetska uprava Republike Slovenije.

Fridl, J., Gabrovec, M., Hrvatin, M., Natek, M., Orožen Adamič, M., Pavšek, M., Perko, D., Peršolja, B., Petek, F., Topole, M., 1995. Geomorfološka inventarizacija Kamniško-Savinjskega regijskega parka. Ljubljana, Geografski inštitut Antona Melika ZRC SAZU, 164 pp.

Kunaver, P., 1949. Na groblji Bistriškega ledenika. Planinski vestnik, 49, 1, pp. 9-20.

LIDAR. 2015. Ljubljana, Ministrstvo za okolje in prostor, ARSO. URL: http://evode. arso.gov.si/indexd022.html?q=node/12 (accessed 15.05.2016).

Lucerna, R., 1906. Gletscherspuren in den Steiner Alpen. Geographischer Jahresbericht aus Österreich. Forschungsberichte aus dem Institut für Geographie und Regionalforschung der Universität Wien, 4, pp. 9-74.

Meze, D., 1966. Gornja Savinjska dolina. Nova dognanja o geomorfološkem razvoju pokrajine. Ljubljana, Slovenian Academy of Sciences and Arts, $195 \mathrm{pp}$.

Stojilković, B., Stepišnik, U., Žebre, M., 2013. Pleistocenska poledenitev v Logarski dolini. Dela, 40, pp. 25-38. 
Šifrer, M., 1961. Porečje Kamniške Bistrice v pleistocenu (The basin of Kamniška Bistrica during the Pleistocene period). Ljubljana, Slovenian Academy of Sciences and Arts, $211 \mathrm{pp}$.

Žebre, M., Stepišnik, U., 2014. Reconstruction of late Pleistocene glaciers on Mount Lovćen, Montenegro. Quaternary International, 353, pp. 225-235.

\section{SLEDOVI ZADNJEGA VIŠKA PLEISTOCENSKE POLEDENITVE V VZHODNIH KAMNIŠKO-SAVINJSKIH ALPAH}

Raziskava o višku zadnjega poledenitvenega sunka je bila opravljena na območju vzhodnih Kamniško-Savinjskih Alp, kjer je potekalo geomorfološko kartiranje glacialnih reliefnih oblik. Čeprav so bili preučeni vsi geomorfološki dokazi, ki pričajo o poledenitvi, je bila posebna pozornost namenjena predvsem dokazom, ki so pričali o zadnjem poledenitvenem sunku. Terensko delo je obsegalo ponovno preučitev ledeniških sledi, omenjenih v dosedanji literaturi (Lucerna, 1906; Kunaver, 1949; Šifrer, 1961; Meze, 1966; Fridl in sod., 1995), v kombinaciji z vsemi ostalimi ledeniškimi in fluvioglacialnimi oblikami na preučevanem območju.

Geomorfološko raziskavo smo izvedli na območju vzhodnih Kamniško-Savinjskih Alp: v Matkovem kotu, Logarski dolini, Robanovem kotu, na Dleskovški planoti in njenih pobočjih ter v dolinah Lučke Bele, Kamniške Bele in Kamniške Bistrice. Znotraj teh območij so predeli, ki jih dosedanja literatura označuje kot tiste, ki so bili pod vplivom zadnjega poledenitvenega sunka. Skupna površina ledenikov na preučevanem območju je bila $40,9 \mathrm{~km}^{2}$. Iz te površine pa je izključen ledenik v Matkovem kotu, kjer morenski material ni ohranjen in ni bilo mogoče rekonstruirati njegovega obsega.

Raziskava je pokazala, da ledeniki niso pokrivali tako velike površine, kot so ugotavljali prejšnji raziskovalci (Lucerna, 1906; Kunaver, 1949; Šifrer, 1961; Meze, 1966; Fridl in sod., 1995). Ledenika iz Matkovega kota in Logarske doline se nista združevala v spodnjih delih obeh dolin, ampak sta bila bistveno krajša. Ledenika nista imela dovolj velikega zaledja, da bi se lahko zbrale tolikšne količine ledu. Led z Dleskovške planote je tekel v Robanov kot na manjšem pregibu in ne po celem pobočju, ki planoto ločuje od te doline. Ledeniki na pobočjih Dleskovške planote med Robanovim kotom in Lučko Belo so pokrivali drugačne površine, kot se je domnevalo do sedaj. Krniški sistemi v dolinah Kamniške Bistrice, Logarske doline in v Matkovem kotu so bili ločeni; površine ledu v teh dolinah se niso stikale.

Raziskava o ledeniških ostankih iz časa viška zadnjega poledenitvenega sunka je osnova za nadaljnje geomorfološko delo na tem območju: na osnovi velikosti in mer krnic, moren in morenskih grebenov bo mogoče rekonstruirati topografijo ledenikov na tem območju, določiti ravnovesno mejo in rekonstruirati klimatske pogoje v tistem obdobju pleistocena. 